\title{
The Way to Understand the Nature and Extent of Judicial Independence in China
}

\author{
Yanrong ZHAO* \\ China University of Political Science and Law, Beijing
}

\begin{abstract}
In order to portray the true extent of judicial independence in China's judicial practices, this article first clarifies the contested meanings of "judicial independence" within Chinese judicial circles and provides a detailed literature review of the main school of thoughts on the extent of judicial independence in China. In contrast to the existing literature-most of which sees judicial independence in China as stagnant-this thesis suggests employing the strategic interaction approach to study the development of impartial adjudication in China and argues that the extent of adjudicative independence is evolving with the amount of judicial discretion afforded by the Chinese Communist Party (CCP) to judges.
\end{abstract}

Keywords: judicial independence, adjudication independence, dynamic definition, strategic interaction

\section{OBJECTIVES OF THIS ARTICLE}

The idea of judicial independence (司法独立) originated in Europe and was further developed in the US by America's founding fathers. ${ }^{1}$ As a multifaceted concept, in a narrow definition, it first served as a touchstone for determining the degree of the court system's capacity to impartially administer justice ${ }^{2}$ and is regarded as essential to the preservation of law and liberty. ${ }^{3}$ Furthermore, it is also believed to have a close link with the political structure of separation of powers designed to minimize government tyranny. ${ }^{4}$ Thus, the introduction of this significant notion to China's

* (赵言荣) PhD, Procedural Law, Civil, Commercial and Economic Law School, China University of Political Science and Law, Beijing, China; PhD, International and Political Studies, School of Humanities and Social Science, University of New South Wales, Australia; Lecturer, Civil, Commercial and Economic Law School, China University of Political Science and Law, Beijing, China. Correspondence to Yanrong Zhao, Civil, Commercial and Economic Law School, China University of Political Science and Law, Beijing 100088, China. E-mail address: smm001@ sina.com. This article is part of the author's PhD dissertation, "The Growth and Limits of Judicial Independence in China," written at the University of New South Wales Australia, funded by the China Scholarship Council Scholarship and UNSW Tuition Fee Scholarship. This article is also supported by the Program for Young Innovative Research Team in China University of Political Science and Law. The author thanks Professor David Lovell and Associate Professor Zhang Jian for their valuable instruction and editing.

1. Bailyn (1992).

2. Cohen (1969), p. 970.

3. Bailyn, supra note 1, p. 85 .

4. Fairlie (1923), pp. 393-436; Stevens (1999), pp. 365-402; Minegar (2011), pp. 383-401. 
political framework ${ }^{5}$ has caused considerable debate among Chinese scholars, Western scholars, and between Western and Chinese scholars. ${ }^{6}$

China is conventionally portrayed as being without judicial independence in a country ruled by a single Party without the political structure of separation of powers. ${ }^{7}$ Moreover, this criticism also has its roots in the Chinese Communist Party (CCP)'s historical policy on the judiciary (司法). As many Western and Chinese scholars have noted, after the CCP was founded in 1921, the MarxistLeninist approach of "using law as a tool-to remould society, suppress class enemies and enforce Party policy," 8 rather than protecting individual rights—-became doctrine. The courts were to serve as instruments for suppressing the enemies of the state. So, as Avino comments, "justice was politicised, class distinctions were made in enforcing justice, and mass trials for political indoctrination were introduced." Such features became an important part of the so-called "lawless" communist system that existed under the rule of Mao Zedong, especially from the Judicial Reform Movement to the end of the Cultural Revolution. ${ }^{10}$ In fact, between 1966 and 1976, during the Cultural Revolution, the preliminarily formed legal system was seriously damaged. Government departments and judicial organs were obstructed while the Constitution and laws were abolished or otherwise disabled. Correspondingly, there was vehement discussion of the ideas of judicial independence and the separation of powers, which were contrary to an instrumental concept of justice. During the period of Cultural Revolution, Chinese scholars argued that the ideas of "separation of powers" and "judicial independence" were spurious; these ideas were put forward to cover the nature of the bourgeois state, which was "to suppress the rebellions of the working class and maintain the bourgeois state," and thus "could never become a reality.","1

However, since the end of the Cultural Revolution, China has implemented extensive reforms to develop a political and institutional transition to facilitate economic growth. This transition involves the CCP's high expectations for the judiciary, given the crucial role of law in ensuring predictability and the stability of property and profits in market-oriented societies. $^{12}$ In order to meet these expectations, judicial reform (司法改革) began in the 1980s with the main goal of establishing a state "rule according to the law." ${ }^{13}$ Consequently, the importance of judicial independence has been rediscovered in China not only among academics and judicial officials, but also in the background and basis of the CCP's so-called new policy of "The People's Republic of China Governs the Country According to Law and Makes It a Socialist Country under Rule of Law (依法治国，建设社会主义法治国家)."14

5. The 1954 Constitution stipulated that "the people's courts adjudicate cases independently, only subject to law" (人民法院独立进行审判，只服从法律). See 中华人民共和国宪法 [Constitution of the People's Republic of China], (c), Article 78, section VI (1954).

6. He (2003), p. 84; Avino (2003), p. 369; Peerenboom (2009).

7. Dam (2007), p. 250; Michelson (2007), p. 353.

8. Chen (1999), p. 34.

9. Avino, supra note 6, p. 376.

10. Ibid

11. Wu (1997), pp. 91-2.

12. At the end of the Cultural Revolution, Deng Xiaoping decided to end the class struggle policy and recreate a legal system that would not change as a result of changes in the leadership of the CCP, and ruled the country by law. Therefore, in the communiqué of the third plenary session of the CCP's eleventh central committee, the "independence of the judiciary" and "faithfulness to the law and regulations" were highlighted. See People.com (1978).

13. Killion (2004), p. 546; Xin (2003), pp. 58-78.

14. According to the official English version of the Constitution of the People's Republic of China released by the NPC, Article 5, section 1. 
Hundreds of new laws have been passed and the role of the courts has been expanded. However, in relation to two issues, namely the extent of judicial independence and understanding the factors that influence the judicial decision-making in today's China, there are still serious debates and sometimes completely opposite viewpoints among scholars, Party-state officials, and even the public. ${ }^{15}$ Some scholars argue that Chinese judges continue to enjoy little judicial independence ${ }^{16}$ and the courts are "fused to the state, embedded in and subordinated to the rest of the government bureaucracies." ${ }^{17}$ Other scholars assert that, as a result of China's judicial reform, "the judiciary has become more competent, authoritative, and independent." ${ }^{\prime 18}$ There are still others who hold a very sharp view that, in China, judicial independence has been completely established, even more than China needs! ${ }^{19}$

Nevertheless, taking a close look at the debates on the extent of judicial independence in China, one can observe that the current debates somehow resulted in the scholars' different ways to define and measure judicial independence. As will be discussed in the following sections of this article, while some scholars focus on judicial adjudication (审判) to explore the different factors that influence the judges' decision-making process, other scholars study judicial independence based on the framework of the US style of "separation of powers," thus criticizing that China has no judicial independence, since its political structure is different from the US style. Moreover, the approaches that different scholars employ to measure the extent of judicial independence are also varied. Appealing to different definitions and measuring approaches to study the extent of judicial independence in China, the scholars painted a blurred picture of it.

However, if there is no consensus on the current situation of judicial independence in China, it will be hard to figure out the existing problems that create obstacles to an independent judiciary (独立的司法), and thus it will be hard to propose effective and satisfying measures to continue judicial reform. Therefore, identifying the extent of judicial independence and the real obstacles to judicial independence is now a matter of urgency.

Moreover, giving a chronological review of the development of the CCP's judicial policies on courts, one can also notice that the extent of judicial independence in China is not fixed, but varies with the amount of judicial discretion afforded by the CCP to judges, and is deeply influenced by China's traditional legal philosophy and the CCP's revolutionary and pre-revolutionary history. During Mao's era, especially in the Cultural Revolution period, due to the CCP's negative attitude on the role of the courts, there was almost no judicial independence. Since the end of the Cultural Revolution, in the Deng Xiaoping and Jiang Zemin's era, the CCP has decided to develop a professional and independent judicial system as the main avenue for dispute revolution. As a result, the CCP gradually delegated the judicial power to the courts and self-refrained its influence on the normal specific case handling, which resulted in the gradual improvement of adjudicative independence. However, during the Hu-Wen era, the CCP has again tightened its control on the judiciary since the early 2000s, thus exerting more pressure on the independent adjudication. The judicial policy on courts changed again in the Xi Jinping era.

\footnotetext{
15. He, supra note 6; Zhao (2008), p. 3; Yang (2013), p. 3; Liang (2010); Dong (2005), p. 6.

16. He (2004), p. 213; O’Brien \& Li (2004), pp. 75-96; Lubman (1999).

17. Michelson, supra note 7, p. 353.

18. Peerenboom, supra note 6, p. 21.

19. Liang, supra note 15.
} 
Therefore, in order to portray the true extent of judicial independence in China's judicial practices, based on China's social and political environments, this article first clarifies the contested meanings of "judicial independence" in discussions about, and within, Chinese judicial circles. In contrast to the existing literature-most of which sees judicial independence in China as stagnant—this article borrows Tiede's definition of regarding judicial independence as a dynamic one to study judicial independence in China, and further argues that the independence of judicial adjudication in China varies with the amount of discretion afforded by the CCP to judges at different times on different issues. It then provides a detailed literature review of the three main schools of thought on the extent of judicial independence in China, and suggests exploring the strategic interaction approach to study the factors that might affect the impartiality of judicial adjudication and how those factors influence and shape the judges' decision-making process to identifying the extent of judicial independence and the real obstacles to judicial independence in China.

\section{DEFINING JUDICIAL INDEPENDENCE}

Any analysis of judicial independence must begin with a core meaning. However, "despite an almost universal consensus as to its normative value" ${ }^{, 20}$ of judicial independence, it might be "one of the least understood concepts" in the fields of political science and law. ${ }^{21}$ A concrete or consistent definition of the term remains disturbingly contested "even in economically advanced liberal democracies known for the rule of law." 22 In Theodore Becker's words, "we all know what it means," ${ }^{23}$ yet "its full significance, intricacies, and implications still seem beyond our reach." ${ }^{24}$ Kornhauser even suspected that politicians and scholars "deliberately" left the term undefined because "they want to keep the term amoebic to change shape to fit the particular context in which it is used." ${ }^{25}$ Consequently, there arises the great need to define judicial independence ${ }^{26}$ before we can decide what makes a judiciary more or less independent. ${ }^{27}$

\subsection{Some Core Issues in Defining Judicial Independence}

Based on Eli M. Salzberger's research, in order to define what judicial independence is, the first step is to define the subject and object of $i^{28}$ or, in Russell's words, to define what exactly is meant by "judicial" and what is meant by "independent." ${ }^{29}$ Clearing the meaning of “judicial” (司法) is especially important in studying China's judicial independence, since it is not a legal term with a clear meaning in China. The 1982 Constitution of China does not

20. Larkins (1996), p. 607.

21. Ibid.

22. Peerenboom, supra note 6, p. 2.

23. Becker (1970), pp. 1-8.

24. Larkins, supra note 20, p. 607.

25. Kornhauser (2002), pp. 45-54.

26. Trochim \& Donnelly (2001), pp. 64-5, 69-71.

27. Ibid.

28. Salzberger (1993), p. 350.

29. Russell (2001), pp. 6-8. 
use the term "judiciary" or "judicial system" (司法系统), but stipulates the court and the procuratorate, respectively. ${ }^{30}$ Thus, for the common people in China, the judicial system generally not only refers to the court and procuratorate system, but also includes the police bureau (公安局) and judicial bureau (司法局). At the same time, Chinese scholars sometimes use "judiciary" to refer to the court system and, at others, to refer to the court and procuratorate system, ${ }^{31}$ yet, in the international scholarship, "judicial system" generally refers to the court system or judges collectively. ${ }^{32}$ In this research, the researcher uses "judicial system" as synonymous with "court system."

While limiting the judicial system to the court system, "judicial" could still refer to individual judges, the overall court system, or part of the court system such as a specific lower and higher court. As Ferejohn argues, it is entirely possible that individual judges are independent but the courts in which they work are dependent on other branches of government. ${ }^{33}$ Therefore, in developing a more workable definition, scholars should also clearly identify whether they are referring to individual judges, a single court, or the whole judicial branch. It is in this sense that some scholars argue that judicial independence is a "multifaceted concept" 34 and can be broken down into different subcomponents: personal decision independence, internal independence, external independence, and collective independence. ${ }^{35}$ In order to simplify the argument to this thesis, I will use the norms of personal independence of individual judges, the collective independence of a single court, and the overall court system to advance this thesis.

After defining "judiciary" as an individual judge, a single court, or the court branch as a whole, the second step is to identify from what the judiciary is independent. ${ }^{36}$ Since courts do not exist or operate in a vacuum, a number of external factors, some political and some social, will influence judges' opinions. ${ }^{37}$ Thus it is generally accepted that the term "independent" is a relative term. Nothing in this world is absolutely independent; courts are never entirely independent. Therefore, the concept must be defined in relation to something else. In Tiede's argument, in the political context, "this generally means independence from such things as the legislature, the executive, higher courts, individual litigants, and corruption, to name just a few examples." 38

Since the term "judicial independence" is ambiguous, it has been interpreted differently by various legal scholars in relation to different legal systems. ${ }^{39}$ The blueprint of judicial independence is usually based on an idealized version of Anglo-American institution ${ }^{40}$ as the idea of judicial independence is carried forward in the US and is regarded as the "hallmark"

\footnotetext{
30. 中华人民共和国宪法 [Constitution of the People's Republic of China], section 7.

31. Zhao, supra note 15 .

32. The Cambridge Dictionary explains "judiciary" as "the part of a country's government that is responsible for its legal system and that consists of all the judges in its courts of law." See dictionary.cambridge.org.

33. See Ferejohn (1999), pp. 353-84. Ferejohn claims that "in the United States, the judges are free to decide the cases but the federal judiciary is institutionally dependent on Congress and the president."

34. Shetreet \& Deschênes (1985), p. 6.

35. Peerenboom, supra note 6.

36. Tiede (2006), p. 160.

37. Larkins, supra note 20, pp. 613-14.

38. Tiede, supra note 36, p. 131.

39. Salzberger, supra note 28 , p. 350

40. Evans (2004), p. 30.
} 
of the US political system. ${ }^{41}$ Thus, some discussions of the origin and substance of judicial independence in the US can provide us with many meaningful revelations.

In the US, judicial independence is deeply rooted in the concern of Framers of the US Constitution about "unbridled governmental prerogative can easily engender an unending cycle of tyranny followed by revolt" from English experience. ${ }^{42}$ The Framers of the US Constitution decided to create a national government restrained by internal checks and balances from tyrannical abuses of its power under the theory of separation of powers. By creating a Constitution authorized directly by the will of the people, the legislative and executive powers are limited to ultimately preserving the security of individual rights. In addition, recognizing the dangers inherent in unbounded power, in order to ensure the separation of powers plan could succeed, the Founders of the US Constitution "went beyond the legacy of British and colonial history" 43 to create an independent judiciary that was absolutely separate and distinct from the executive and legislative branches, and granted it the power to hear all cases "arising under the Constitution and laws of the United States."44 The judiciary thus was mandated to check abuses of constitutional limitations by the other two branches. As a result, this innovation pushes the judiciary into an "unaccustomed role a co-equal branch of government, with the ultimate authority to interpret the Constitution's limitations on the powers claimed by the national government itself." 45

In the US, judicial independence relates not only to the individual judges, but also to the scope of authority of the judiciary (法院系统); the judiciary as an institution is independent from the legislative and executive branch. However, "at the most basic level,"46 the "essence" or the "core feature" of judicial independence is the preservation of the judiciary as a distinct institution, as one that can adjudicate cases as a "neutral third" with impartiality. ${ }^{47}$ As noted by Martin Shapiro, the requirement of "impartiality" is at the root of the "social logic" of the court for fear that dispute resolution becomes a "two against one" situation. ${ }^{48}$ That means that the dispute can only be resolved by a neutral third party "who can be trusted to settle controversies after considering only the facts and their relation to relevant laws." 49 Based on the above belief, Kaufman notes that, dating at least to the time of Lord Coke ${ }^{50}$ the hallmark of every true judicial tribunal has been impartial adjudication. ${ }^{51}$ The long struggle to separate courts and judges from other institutions and functionaries of the government in England was designed to place judges above the self-interest that motivates the disputing parties. $^{52}$ The significance of identifying the essence of judicial independence as "impartial

\footnotetext{
41. Rosenberg (1992), p. 369.

42. Kaufman (1980), p. 671.

43. Ibid.

44. Ibid.

45. Ibid.

46. Larkins, supra note 20, p. 608.

47. Kaufman, supra note 42, pp. 671-701; Gibson (2009), pp. 1285-304; Nicholson (1993), p. 404; Shapiro (1981), p. 17; Fiss (1993), pp. 57-76.

48. Shapiro, supra note 47 , pp. $1-8$.

49. Ibid

50. See Dr Bonham's Case, 8 Co. Rep. 107, 118, 77 Eng. Rep. 638, 652 (C. P. 1610) ("No man ought to be a judge in his own case").

51. Kaufman, supra note 42, p. 692.

52. Shapiro, supra note 47.
} 
adjudication" is that it explains that judicial independence is not an end in itself; rather, it is a way of impartially making judgments as a means to achieving justice. Correspondingly, this thesis will focus on "impartial adjudication" to study judicial independence in China.

In addition, since traditionally administrative agencies have had the greatest power to influence the decision-making process of the judiciary, judicial impartiality is most seriously compromised when another branch of government appears as a party to the litigation. To prevent administrative agencies from enlisting the judiciary in a campaign to undermine the Constitution, the judiciary "must be insulated from congressional or executive attempts to distort the independent exercise of judicial judgment." ${ }^{\text {"53 }}$ Thus, more than an affirmative grant of authority to the judiciary, Article III of the US Constitution also explicitly prohibits interference with the exercise of judicial power by the legislative and executive branches. This safeguard, called the second trait of independence- "political insularity" 54 _ensures that judges should not be used by other political authorities as tools to achieve political goals, nor punished for preventing their realization. In order to achieve this objective, the judiciary is institutionally separate and distinct from "other branches of the government" "electorally unaccountable." At the same time, the Constitution of the US guarantees that judges and justices can enjoy the lifelong appointments with undiminished salaries to strengthen the judges' ability to resist the possible political pressures. ${ }^{57}$ In theory, this independence, plus its constitutional review power to the legislative and executive acts, allows courts to "stand as the ultimate guardians of our fundamental rights." 58 Later, the separation of powers was extended by case-law from merely specific prohibitions of salaries and tenure provisions to "embrace all significant intrusions upon the exercise of the judicial power." 59 In these ways, the US Founders ensured that federal judges maintained their independence from political bodies, not only in relation to their appointment and salaries, but also more significantly by providing them with the power of constitutional review. ${ }^{60}$ Impartiality and insulation from pressures by political branches are essential attributes of judicial power.

Although the judiciary's role in the impartial adjudication is generally agreed, there are debates on the judiciary's other role of constitutional interpretation to check and balance the legislative and executive branches. As Shapiro argues:

in a great many nations, judicial independence is conceived not in terms of a tripartite constitution with checks and balances but simply in terms of a professional judiciary sufficiently insulated from other governmental influences to operate within its own sphere under the law. ${ }^{61}$

It is true that judicial independence regarding separation of powers is, as Garapon argues, "too closely linked to the American perception of politics and obviously grounded in

53. See Chandler v. Judicial Council, 398 U.S. 74, 103 (1970) ("the power to direct trial judges in the execution of their decision-making duties ... [is] a judicial power, one to be entrusted only to a judicial body").

54. Fiss, supra note 47, pp. 59-60.

55. Valelly (2009), p. 187.

56. Ibid.

57. Ibid.

58. Horsky (1957), p. 1111.

59. Kaufman, supra note 42, pp. 687-8.

60. Ibid., pp. 686-7.

61. Shapiro, supra note 47, p. 32. 
American history." ${ }^{262}$ For example, in the courts of Great Britain, Czarist Russia, and other European countries, judicial independence is mainly about independent adjudication. The court system in these countries also enjoys significant levels of independence depending on the degree to which the judicial institution has a distinct and discrete role in case adjudication. To guarantee their independent adjudication function, through strict institutionalization of the court system, these court systems are "detached from the interest of the political system, the concerns of powerful social groups, and the desires of the general public." However, they do not enjoy a co-equal status with government and have no power of constitutional review.

Furthermore, even Larkins, a US scholar, who believes that "judicial independence is not meaningful if the courts cannot exercise it to check the arbitrary or unjust exercise of power by political actors," ${ }^{64}$ admits that, in countries that are experiencing transition from a historically dependent judiciary into an institution that can operate forcefully vis-à-vis other political and societal institutions, this transition can operate properly only when courts "are comfortable and secure in their position as constitutional adjudicators." ${ }^{25} \mathrm{He}$ argues that this applies to countries for which the first step is to provide the judiciary with an environment to undergo a process of institutionalization. ${ }^{66}$ In Larkins's view:

a more institutionalized judiciary is by default more independent not only because one of its defining characteristics is autonomy, but also because an institutionalized judicial system implies one which has a broad scope of authority within the political system. ${ }^{67}$

Larkins believes that, if it develops properly in a stable political environment and becomes stronger over time, the judicial system could eventually become an organization with "adaptability, complexity, autonomy, and coherency,"68 which in the end would enable the judiciary to assert their independence within the constitutional system.

That is the same in China. According Article 126 of the Constitution of China (1982), which is regarded by scholars as the origin of independent adjudication in China, ${ }^{69}$ "the people's courts exercise judicial power (审判权) independently, in accordance with the provisions of law and not subject to interference by any administrative organ, public organisation or individual." 70 Although many Chinese scholars use the term "judicial independence" (司法独立) to study the status of judges in the decision-making process, quite a few Chinese scholars specifically use the term “adjudicative independence" (审判独立) to demonstrate the uniqueness of China's judicial independence. ${ }^{71}$ As Professor Chen Guangzhong argues, “'judicial independence' is an international legal term, which is commonly used in the international legal document. It generally refers to the courts and judges'

62. Garapon (2009), p. 42.

63. Larkins, supra note 20, p. 611.

64. Ibid.

65. Ibid., p. 620.

66. Ibid.

67. Ibid., p. 621.

68. Huntington (2006), pp. 12-32.

69. Chen (2013), p. 1; Lubman, supra note 16; Avino, supra note 6.

70. 中华人民共和国宪法 [Constitution of the People's Republic of China], Article 126.

71. Zhao, supra note 15 . 
adjudicative independence." 72 Meanwhile, many international scholars use "judicial independence" mainly referring to adjudicative independence. ${ }^{73}$ Therefore, this article will use the term "judicial independence" to process this study, but mainly focus on adjudicative independence to study the position of court system or judges and factors that influence judges' decision-making process.

\subsection{The Approaches to Measure Judicial Independence}

After defining some core issues about what the term "judicial independence" means, another controversial issue is how to measure the extent of adjudication independence. Different scholars use different approaches to measure it, and often confuse the approach of measuring with the definition of it. Following the Constitution of the US, which positively prohibited the interference of other political actors in the judicial system, a prominent way of researching judicial independence is to refer to "a variety of formal institutional protections that are designed to induce impartiality or power or both" "74 using an institutional approach. Some scholars even confuse it with the definition of judicial independence and call it the "institutional definition" of judicial independence. ${ }^{75}$ Within this approach, scholars "focus on institutional or structural variables that allegedly enhance or inhibit judicial independence" 76 such as life tenure, judicial-controlled judges' appointments, promotion and dismissal, and judicial-controlled administration of the budgets. The pursuant of independent courts hinges exactly on the assumption that the institutional shields prevent external actors from influencing judicial output, which in turn ensures equal responsibility and protection under the law and provides stable protection of property rights. ${ }^{77}$ Consequently, many scholars believed that institutional judicial independence is higher when there are more structural safeguards against interference by non-judicial actors in the judicial decisionmaking process. ${ }^{78}$

Scholars focus on institutional guarantees against undue influence on judicial decisionmaking at least in part because it is an easily operated way of measuring the degree of judicial independence, since "identifying these structural shields is a fairly straightforward measurement task." 79 However, this approach has been criticized by a few scholars who argue that it does not define judicial independence explicitly, but simply states which conditions are conducive to its existence. ${ }^{80}$ In addition, there is mounting empirical evidence that makes this assumption problematic. For instance, Clark created a "judicial effectiveness score" to measure the institutional independence of Latin American Supreme Courts. In his test, he used indicators such as tenure guarantees, methods of appointment and removal of judges, and salary guarantees for each court. However, surprisingly, he found that courts such as

72. “司法独立 [judicial independence], 是国际通行的法律术语, 为国际法律文件所惯用。其含义一般是指法 院和法官的审判独立.” See Chen, supra note 69, p. 1 .

73. He (2007), pp. 203-25; Peerenboom, supra note 6; Liebman (2005), pp. 1-157.

74. Clark \& Staton (2011), p. 12.

75. Tiede, supra note 36 , p. 136.

76. Ibid., p. 129.

77. Popova (2006), p. 15.

78. Vanberg (2008), p. 7.

79. Ibid., p. 15.

80. Tiede, supra note 36, p. 136. 
those in Argentina, which are generally supposed to be less independent, actually gained much higher scores than those apparently more independent ones. ${ }^{81}$ In a study of the Italian judiciary, Guarnieri found that the institutionally independent Italian judiciary could not guarantee neutral judgment when the political department was one party of the litigation and individual judges were under the undue influence of the media and the mafia. ${ }^{82}$ The "global best practices" 83 developed within the institutional approach to promote the level of judicial independence is also criticized as ignoring culture and downplaying "local politics and the competing interests that often undermine reform efforts." ${ }^{\prime 4}$ Therefore, although some of the institutional guarantees against undue influence on judicial decision-making are conducive to the development of judicial independence, the "international best practices" cannot be used to decide the existence or extent of judicial independence. Correspondingly, this article takes the position that the institutional configuration of the judiciary should be treated as an independent variable in the analysis of judicial independence, but should not be used as a measure of its independence.

The institutional definition of judicial independence also gives rise to occasional disconnect between de jure and de facto judicial independence. ${ }^{85}$ Clark further argues that judicial independence also has a behavioural definition, ${ }^{86}$ namely "the extent to which judges' choices are self-determined and/or effective." ${ }^{, 87}$ In order to measure behavioural judicial independence, some scholars employ "judicial rulings against the government approach.", 88 These scholars examine the outcomes of the courts as a reference to measure judicial independence. By examining the frequency with which courts decide cases against the government, the scholars argue that, if the courts did this often, it might be inferred that they enjoy enough independence to challenge the government when political wrongdoings arise. On the contrary, given that most judicial decisions favour government policy, it is reasonable to deduce that the courts are unable to critically supervise the government policy or behaviour. ${ }^{89}$ However, while evidence that courts have ruled against the government may signal a healthy judiciary, once again, this approach does not explain specifically from what the judiciary must be independent in order to issue such anti-government decisions. ${ }^{90}$ Therefore, this thesis will not apply "judicial rulings against the government approach" to measure judicial independence in China.

\subsection{The Definition of Judicial Independence Used in this Study}

Since it is difficult to identify and measure judicial independence using both "the institutional approach" and "the outcome-against-government approach," a variety of scholars employ another approach to study judicial independence that is grounded in the positive political

81. Clark (1974), p. 405.

82. Guarnieri (2001), pp. 111-30.

83. Henderson (2009), p. 24.

84. Garapon, supra note 62, p. 38.

85. Clark \& Staton, supra note 74, p. 12.

86. Ibid.

87. Ibid.

88. Ramseyer (1994), pp. 721-2.

89. Casanova et al. (1970), pp. 21-4.

90. Larkins, supra note 20, p. 617; Tiede, supra note 36, p. 149. 
theory of law, namely the "strategic interaction approach." 91 These scholars do not focus on specific institutional variables or preferences of justices for the best policy outcomes. Instead, as McNollgast shows, judicial independence is essentially linked to the judiciary's need to rely on other branches to enforce its judgments. ${ }^{92}$ The Constitution of the US designed a check and balance power structure. Each branch is independent from each other, but also dependent upon each other. Therefore, McNollgast argues that, if judges, government, and law-makers all seek to pursue their own incompatible policy objectives, in order to accomplish its purpose, each group needs to take the others into account. Moreover, a court must depend on the government to implement its interpretations of the laws. Similarly, the government must obtain support from the legislative branch if it wants to implement its policy and is to be given sufficient resources to enforce the court's decisions. ${ }^{93}$ Meanwhile, the courts' authority in interpreting and enforcing law depends on the powers and resources delegated by the legislation.

Thus, based on the positive political theory, which "is concerned with understanding political phenomena through the use of analytical models which, it is hoped, lend insight into why outcomes look the way they do and not some other way," 94 the court is "constrained to act within limits that are acceptable to other political actors" in pursuing its own policy objectives. ${ }^{95}$ This theory is echoed by Epstein and Knight, who explain that "justices are strategic actors" who realize that the attainment of their goals depends on their understanding of the preferences of other actors. ${ }^{96}$ Accordingly, they looked at the interaction between different levels of courts as well as the interaction between the judiciary and other branches of government with elected members to study the judges' decision-making process. ${ }^{97}$ Using such a strategic interaction model, McNollgast finds that "judicial independence waxes and wanes with changes in the political composition of our three branches of government." 98 According to this approach, judicial independence is better defined as "strategic interaction" among political actors that is not fixed, but fluctuates. ${ }^{99}$

Borrowing from McNollgast's positive political theory, Tiede proposes a two-part definition of judicial independence: “judicial independence' can and should be defined as the judiciary's independence from the executive, as measured by the amount of discretion that individual judges exercise in particular policy areas." 100 First, "at a minimum, judicial independence is defined as the judiciary's independence from the executive branch in any given country." ${ }^{101}$ Tiede explains that he defines it in this way because, in America's political structure, courts can never be completely independent from the legislature, as it is supreme in making the laws that judges interpret in particular cases and it provides funding

91. Political theory of law "is primarily a positive theory of rational strategic behavior in the presence of imperfect information that seeks to explain and predict the content of the law." See McCubbins et al. (2005).

92. Ibid.

93. Shapiro (1988).

94. Austen-Smith \& Banks (1998), p. 259.

95. McCubbins et al. (1994), p.6.

96. Epstein \& Knight (1997), p. 2.

97. Ibid., pp. 56-111.

98. McCubbins et al. (2006), p. 109.

99. Ibid.

100. Tiede, supra note 36, p. 131.

101. Ibid., p. 134. 
for courts and their personnel. ${ }^{102}$ Second, derived from McNollgast, who posits that judicial independence is discretion that fluctuates depending on the political composition of government and strategic interaction between branches of government, ${ }^{103}$ Tiede further explains that, if the judiciary is independent from the executive, it may be measured by the amount of discretion delegated by the legislative body to the individual judges "at any particular moment in time, concerning any specific area of the law." ${ }^{104}$ Meanwhile, in Tiede's views, the amount of judges' discretion at any specific time also relates to the issue at stake. When the law-makers regard some issues as politically salient, they can use different legislative skills to curtail or expand the amount of discretion that judges may enjoy to make decisions in particular areas of the law. For example, legislative bodies can intentionally make legal provisions in a general and vague language to provide judges with wider discretion in deciding how to apply the law in specific cases; or they can offer specific instructions to judges to curtail judges' discretion. ${ }^{105}$ Defined in this way, judicial independence "is not fixed or stagnant, but is fluid and changeable."106

The first part of Tiede's definition of judicial independence has some problems. Since he accepts the positive political theory and admits that judicial independence is a relative term, ${ }^{107}$ he simply limits the object of judicial independence to the executive, not including the legislative conflicts with his previous views. As explained by positive political theory, judges, government, and law-makers all need to take others into account if they seek to pursue their own incompatible policy objectives. ${ }^{108}$ Even in the US, the judicial system cannot be completely independent of the executive, as the justices in the Supreme Court are nominated by the president and the implementation of judgment also depends on the executive. Thus, sticking to the relative meaning of judicial independence, the object of judicial independence should be defined in a particular political regime. All the factors that could influence impartial adjudication should be identified through detailed fieldwork and analyzed as to their effects on impartial adjudication.

However, the second part of Tiede's definition regards judicial independence as "not fixed or stagnant, but as fluid and changeable according to the amount of judicial discretion afforded to judges at any particular time on different issues"109 and does shed light on a useful way to study and understand judicial independence in China. Within the US power structure, the legislative body enjoys the power to make law to expand or limit the discretion of judges. Hence, Tiede argues that judicial independence fluctuates according to the legislative instruction. ${ }^{110}$ In China's political framework, we need to change the legislative body to the CCP because the CCP is the real source of any power in China.

Using Tiede's definition of regarding judicial independence as a dynamic one to study judicial independence in China has several advantages. First, it reflects the reality of China's

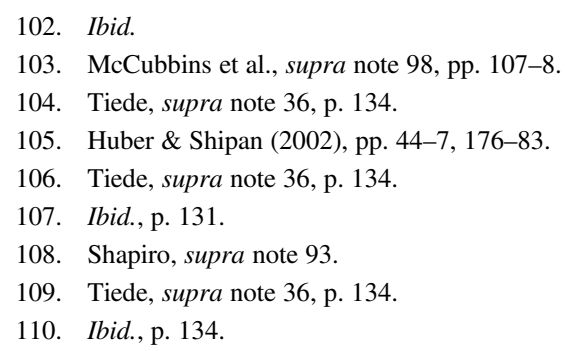


politics and acknowledges that courts may be dependent on other branches of government for funding and personnel choices and certainly on the CCP's delegation of judicial powers that the judiciary enjoys. Second, it provides us with a practical way of measuring the degree of judicial independence in China, which is by examining how judges make decisions within the range of acceptable discretion granted to them by the CCP. ${ }^{111}$

Admitting Tiede's definition is a useful means to study judicial independence in a dynamic way, there are still other problems about what the discretion is, since there is also little agreement on the exact meaning of "discretion." 112 However, the basic meaning of discretion is generally used by courts, judges, and legal scholars simply to "a person [who] has the authority to decide, or unconstrained choice." For example, Professor Westen states that "discretion means ... an area within which the discretion-holder has authority to adopt, or not to adopt, whatever rule he deems fit." 113 Thus, it is clearer to replace "discretion" with "authority" of the judiciary or judges.

However, examining the authority of judicial independence to identify and measure judicial independence is still a hard task, as the extent of judicial authority is not fixed. Thus Larkin suggests that, instead of looking for evidence of independence, it is much easier to look for evidence of dependence. ${ }^{114}$ This means one should identify obstacles to the exercise of independence - that is, to judges' impartiality and insularity and the courts' institutional scope of authority. Larkin further explains that "too often scholars look for independence when it is quite likely that in its pure form it does not exist anywhere. Judicial dependence, by contrast, exists in virtually every political system and is much more easily identifiable." 115

Assessing judicial independence in this manner is to be conducted through a careful interpretive exercise in which the structural conditions of the courts are analyzed along with the judiciary's functional relationship with other political institutions. Identifying the obstacles to judicial independence in the context of an interpretive exercise can provide great insights into the strength of a judicial branch. ${ }^{116}$ Therefore, to study the nature and extent of judicial independence in China, this article argues that we should comprehensively apply this approach and the strategic interaction approach to conduct a detailed examination of the different factors that influence independent adjudication, how the courts interact with these factors, and how judicial behaviour is influenced and the decision-making process is shaped in a given-Chinese- structural condition of the court.

\section{DEBATES ON CHINA'S JUDICIAL INDEPENDENCE}

As discussed above, the idea of judicial independence was developed in Europe and carried forward in the US by America's founding fathers ${ }^{117}$ and serves as a touchstone for measuring the extent to which a nation's courts can be considered to have the ability to impartially

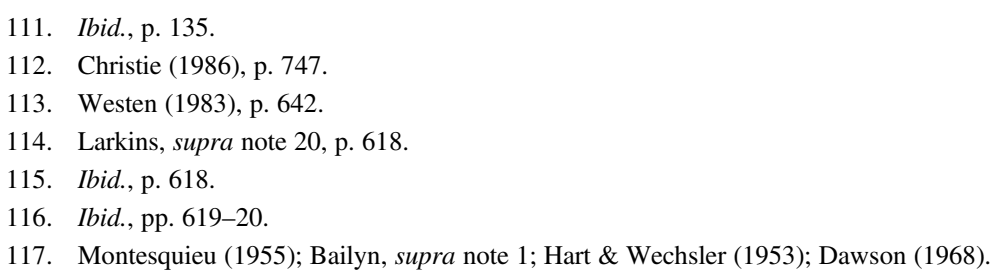


deliver justice, between individuals as well as individuals and government. ${ }^{118}$ It was first introduced into China in the late Qing Dynasty as a goal of judicial reform, ${ }^{119}$ and was accepted by the Beiyang and Nanjing Republic government as rhetoric to legitimate their authority. ${ }^{120}$ The independence adjudication was also stipulated in the first Constitution of new China in $1954 .{ }^{121}$ Unfortunately, nearly all the modern legal concepts and the legal construction were destroyed in the Revolutionary Culture. As a result, when this Western notion was reintroduced into China after 1979, much research was devoted to the general theory of judicial independence in international scholarship, but the comprehensive research on the situation of judicial independence in China is comparatively small. ${ }^{122}$ Through careful examination of current literature, three main schools of thought can be identified based on their different approaches to study judicial independence in China: the "International Best Practice" School, the "China's Special Condition," and the "Strategic Interaction" School. Both the "International Best Practice" and the "China's National Situation" Schools employ the institutional approach to study judicial independence, but the latter school insists that China's different institutional designs must be understood properly. In contrast, although without being made explicit, the third school employs the strategic interaction approach to study judicial independence.

\subsection{The "International Best Practice" School}

The traditional wisdom of the international scholarship is to criticize China for its lack of judicial independence due to China's institutional obstacles - chiefly the CCP's leadership without US-style separation of powers. ${ }^{123}$ This school of thought defines judicial independence in a broad way, connecting it with the political structure of "separation of powers" and claim that judicial independence means judges should have "judicial review powers.",124 Believing that judicial independence refers to "a variety of formal institutional protections designed to induce impartiality or power or both," 125 these scholars focus on "institutional and structural variables that allegedly enhance or inhibit judicial independence"126 - the so-called "international best practice" 127 — to assess and measure China's judicial independence. Consequently, the one Party system is regarded as "the most significant structural challenge to an independent judiciary in China"128 and the courts' connection to the CCP "presents major institutional obstacles to judicial independence." ${ }^{129}$ Specifically, many

\footnotetext{
118. Cohen, supra note 2; Bailyn, supra note 1.

119. Tay (1987), p. 564. China." However, this book is actually a collection of articles written by 13 authors.

123. He (2002); Dam, supra note 7.

124. Henderson, supra note 83, p. 25; Avino, supra note 6, p. 370.

125. Clark \& Staton, supra note 74, p. 12.

126. Ibid.

127. Henderson, supra note 83, p. 24.

128. Mcpherson (2008), p. 795.

129. Ibid., p. 797; Chow (2015), p. 199.
}

120. Xu (1997), pp. 1-28. See also Article 80 of the Constitution of the Republic of China.

121. 中华人民共和国宪法 [Constitution of the People's Republic of China], Article 78, section VI (1954).

122. Through Google research, there is only one book in particular studying the situation of judicial independence in China, named Judicial Independence in China-Lessons for Global Rule of Law Promotion. In the introduction to this book, the editor, Randall Peerenboom, also comments: "this is the first book in English on judicial independence in 
scholars believe that, because of the Party's veto power in the appointment and promotion process and the power to sanction and dismiss judges, judges in China have no security of tenure $^{130}$; and that most Chinese judges are appointed for political reasons, yet lack legal training. ${ }^{131}$ As a result, judges are believed to be pressured to make decisions that favour the interests of the Party, ${ }^{132}$ otherwise they would find themselves out of favour and risk the loss of their offices. ${ }^{133}$

To the unique institutional arrangements in China's judiciary-the Political and Legal Committee (PLC 政法委员会) and adjudication committee (审判委员会)—one major view is that the PLCs were established by the CCP to "ensure that courts and judges act in accordance with Party dictates" 134 and asserts that the adjudication committee can be readily imagined as "nothing more than an ideological enforcer, routinely disciplining judges who put legal craft above Party loyalty." 135 Consequently, it has been concluded that, even though the Chinese Constitution provides the independent adjudicative power to courts, in practice, "judges follow the dictates of the Party's leadership." ${ }^{136}$ In addition to this criticism of the CCP's role in the judiciary, the fact that courts at all levels are dependent on budgets adopted by government agencies is also criticized by some scholars as a further barrier to judicial independence. ${ }^{137}$ Thus some scholars argue that by far "the greatest threat to judicial independence in China" comes from the fact that "judges are dependent on local governments for appointment, promotion, and, until recently, funding and material security." 138 Moreover, Avino further points out that "the Supreme People's Court, upper-level judicial officers, the procuratorate, the people's congress and the masses" also hold the power to oversee the work of judges, which reduces the judges' adjudicative independence. $^{139}$

Defining judicial independence in the framework of "separation of powers" and applying "the international best practice" approach to measure the extent of judicial independence in China, this school of thought argues that China should reform its judiciary according the “rule of judicial (司法规律)” and thus criticizes China's court system and judges with different institutional arrangements in China's political structure as having no judicial independence in general. Nevertheless, in their specific analysis of China's judicial system, many scholars still focus on the institutional arrangements that guarantee adjudicative independence $^{140}$ and provide some useful institutional variations that affect judicial adjudicative independence in particular, such as the tenure of judges, the process by which judges are appointed and promoted, the funding resources of courts, etc. These variations have significant influence on independent adjudication.

\footnotetext{
130. Lee (1997), p. 380.

131. Avino, supra note 6, p. 380.

132. See UN Comm'n on Human Rights, "Report of the Special Rapporteur on the Independence of Judges and Lawyers," 124 UN Doc. E/CN. 4/2004/60/Add. 1 (4 March 2004).

133. Yardley (2005).

134. Chow, supra note 129, pp. 197-8.

135. Upham (2005), p. 1703.

136. Lubman, supra note 16, p. 394; Avino, supra note 6, p. 381.

137. Song (2007), pp. 141-8.

138. Ginsburg (2010), p. 257.

139. Avino, supra note 6, p. 382.

140. Henderson, supra note 83, p. 28.
} 
However, since these variations are derived from the theoretical analysis of the institutional design modelled in the US political theory, if they are used to be the necessary conditions to assess the situation of a judicial system in other countries, this approach fails to respect specific culture and politics. As Antoine Garapon argues, the institutional approach ignores culture and politics and is inconsiderate of the way legal systems actually develop. ${ }^{141}$ Suli shares Garapon's idea and further notes that China "should not take a model deeply embedded in the historical, institutional, theoretical, and discursive contexts of the West, decontextualize it, and accept it uncritically as the standard of reference for China's experience."142

In addition, the "International Best Practice" School also has problems in providing credible evidence to support its claims and ignores the real practices of the judiciary and the changing situation of the extent of judicial independence in China over the past 40 years. Actually, nearly 40 years after the CCP decided to change its ideology from "rule by man" (人治) to "rule of law" (法治), although the effect of "rule of law" in China is debated, ${ }^{143}$ the real practice of the judiciary has changed a lot. For example, although, according to the Judges Law, the standing committees of the people's Congress at the corresponding levels have the power to appoint or remove judges, ${ }^{144}$ in reality, very few judges were removed from their office without proper cause. At the same time, with the changing situation of the judicial system, the style of judges' selection and promotion and funding resources are gradually controlled by the courts themselves. ${ }^{145}$

\subsection{The "National Situation" School}

The institutional approach of advocating international best practices in China is challenged by the "China's National Situation" School, which argues that, rather than referring to "international best practice," the existing situation in China must be taken into account to better understand judicial independence there. ${ }^{146}$ Using a historical-cultural approach, this school refutes the "universal civilization" idea. ${ }^{147}$ Rather than regarding judicial independence as "a variety of formal institutional protections," 148 this school connects judicial independence to the core feature of the rule of law: impartiality in judicial adjudication. ${ }^{149}$ Therefore, contrary to the "more independence, more justice" theory supported by the first school, they argue that judicial independence is not an end in itself, but mainly aims to sustain judicial impartiality in judicial adjudication. ${ }^{150}$

Based on this theory, this school first examines the Party's leadership over judicial matters. Zhu Suli, for example, argues that the CCP is "an integral component around which the judicial system revolves" and must be treated "as a constituent element of the political and legal system or as a constitutional structure." 151 As a result, "no matter how much it deviates

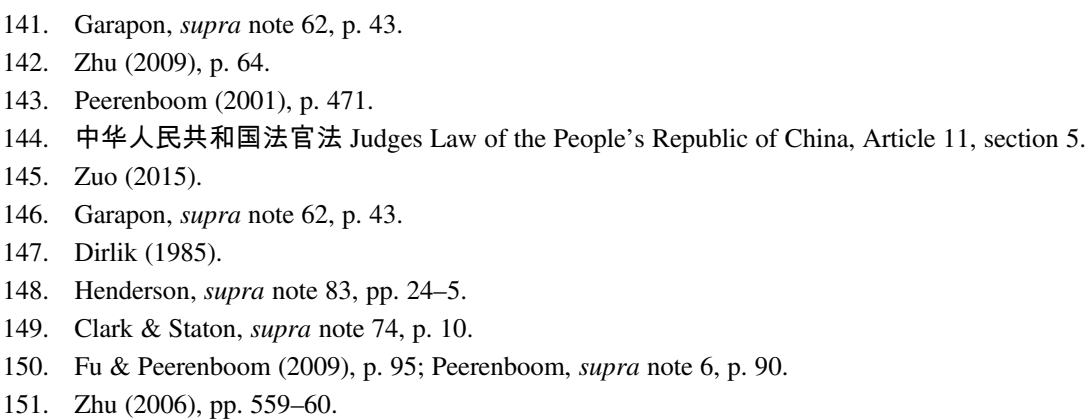


from the 'standard' or the experience of Western countries," this system "should be seen as something normal and not as a freak or an anomaly produced by mistaken theories and viewpoints."152

Zhu Suli's argument raises a debate on how to assess the CCP's influence on the judiciary. Contrary to many scholars' arguments that the CCP's leadership is the main institutional obstacle to an independent judiciary, ${ }^{153}$ Zhu Suli emphasizes that, since the beginning of the reform era, the Party's influence "has diminished" and "its role has changed toward macromanagement and policy setting" because of "the considerable de facto separation of the Party and state that has been taking place since the early 1990s."154 The Party's own goals that require a fair and efficient resolution of disputes are also noted to avoid overstating the degree and nature of Party influence. ${ }^{155}$ In order to better understanding the Party's influence on specific case adjudication, a new analytical framework designed to "differentiate among types of cases, sources of interference, and levels of courts"156 has also been developed to examine the Party's influence in real judicial practice.

Moreover, the need for balance between judicial independence and judicial accountability to prevent judicial corruption is also used by some scholars to rationalize the Party's influence on the judiciary. These scholars argue that the essence of judicial independence is to guarantee impartial adjudication; to that end, the CCP's oversight has discouraged to some extent judicial corruption and judicial arrogance at least. ${ }^{157}$ To explore these observations further, this school highlights the importance of institutional creation and argues that, rather than institutional transformation, China may develop institutions that function well within the Chinese context as the story of Meiji Japan shows. ${ }^{158}$ Consequently, Zhu Suli argues that institutions such as adjudicative committees, or the political-legal committees, were developed to respond to particular needs, namely either to ensure that judicial decisions are keeping in line with macro-level development goals or to effectively resolve cases that frequently arise from inherent limitations in a country's economy or social welfare system. ${ }^{159}$

Second, in order to better understand the situation of judicial independence in China, this school notes the differences between urban and rural courts in the development of judicial independence. ${ }^{160}$ The uneven level of professionalism and the often-corrupt attitudes of grassroots judges even make some scholars wonder how much independence should be given to the judiciary at the local level, ${ }^{161}$ because they may not be professionally ready to act independently. ${ }^{162}$

Third, reference to guanxi has also been noted by some scholars as being China's most dominant culture. As Stanley points out, because Chinese society and Confucianism demand

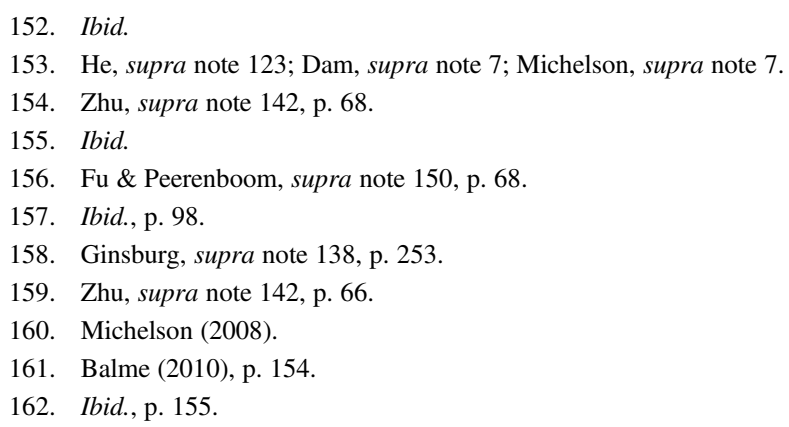


that "harmony be achieved through the maintenance of proper relations," 163 it is common for Chinese judges to accommodate their decisions in cases "to maintain good relationships with powerful persons, institutions or companies."164

This school of thought also employs the institutional approach to study the institutional arrangements of the judicial system and its influence on judicial adjudicative independence. But, contrary to the "international best practice," which is rooted in the US political model of separation of powers, this school focuses on specific case adjudication and highlights the connection of judicial independence to the essence of judicial independence-impartialityto evaluate judicial independence. The essence of judicial independence is to guarantee impartial adjudication rather than "more independence more justice." Moreover, this school sheds light on the importance of "keeping an open mind and understanding the development of the Chinese judiciary in its own historical and social context." ${ }^{165}$ This school also identifies factors in variables that are important to understand judicial independence in China's historical, cultural, and political context. These include doing research in the framework of the leadership of the CCP and considering the differences between the urban and rural areas, and the importance of guanxi in influencing judges' independent adjudication.

Although the second school has many advantages when studying judicial independence in China, this study finds that it fails to capture the interaction between the judicial system and other political or social actors, and thus has failed to capture the active role of the courts in developing judicial independence in China. Moreover, in examining the relationship between the leadership of the CCP over the judiciary, this school discovers the general trend of the CCP's diminishing role on influencing judiciary; however, it does not capture the dynamic process of the CCP's control on judiciary. Third, although this school identifies different factors that affect the independent adjudication in China, the degree of these different factors (especially the most important factors) that influence adjudicative independence is not clearly classified.

More importantly, apart from the deeply institutional research in China's context, it seems that more fieldwork results are needed to support their research. To gain a realistic picture of the problems faced by courts in China and of possibilities for their reform, we have to first identify both the existence and the extent of the CCP's influences on the impartiality of judicial behaviour. Second, we need to consider the courts' and judges' ways of handling these influences, and assess the costs and benefits of specific instances of such influences and of the practices as a whole. ${ }^{166}$ Hence, there is a need for a more detailed empirical study of the various channels and methods of influence and the impact of those influences. In addition, given the wide variation in China, the study should be conducted in different regions and distinguish between different levels of courts and types of cases. As Suli argues, it is on empirical research, rather than some abstract notion of judicial independence, "that a study of Party-judiciary (and other) relations in contemporary China should proceed." 167

\footnotetext{
163. Lubman, supra note 16, p. 396.

164. Finder (1995), pp. 63-73.

165. Zhu, supra note 142, p. 53.

166. Fu \& Peerenboom, supra note 150, p. 100.

167. Zhu, supra note 142, p. 60.
} 


\subsection{The "Strategic Interaction" School}

The third school shares the second school's viewpoints about the need to study judicial independence based on China's own historical and social context, but it absorbs the "competition theory" 168 to explain the situation of judicial independence in China. Drawing on Nagel's notion of power ${ }^{169}$ in defining judicial independence, the third school regards courts in China as an actor of power, and discovers the crucial importance of the political environment to the manner in which the court uses its powers ${ }^{170}$; moreover, it highlights the unified account of the multifaceted interactions between courts and other powers in a country. ${ }^{171}$

Although the third school admits that the courts are a separate power, it still focuses on judicial adjudication to study how a stronger judicial power shapes the judicial independence in China. ${ }^{172}$ It admits institutional independence is not yet sufficiently developed in China, and that judges are often subject to pressures exerted by their supervisor, the political-legal committees, and departments of justice in China. ${ }^{173}$ However, as he contends, rather than an institutional approach, the best way to understand state power, including the role of the judiciary, is by examining the "interactions between various authorities at multiple levels" 174 to see how they interact with various social groups and how the judicial outcomes are influenced by these interactions.

Contrary to regarding the judiciary as simply a passive instrument of the various levels of governments and the Party, they assert that, during the judicial reform, with the professionalization of the personnel of the judicial institutions, a new "power centre" including judges and lawyers has been built in China. ${ }^{175}$ In this new "power centre," judges' and lawyers' interests lie in working to consolidate and boost their own organizations, even though they may also be CCP members or heed the pressure exerted by various outside powers. ${ }^{176}$ In Cabestan's words, "their sheer existence and the steady development of their activities have gradually forced the 'traditional' communist institutions to enter into new types of bureaucratic disputes and adjust, show occasional restraint, bargain, or even reform." 177

This third school highlights the significance of judges' professional qualifications, her/his identification with the requirements of the judicial role, especially the impartial adjudication of disputes, and the larger legal profession in keeping with judges' impartiality. ${ }^{178}$ As Galo argues, the extent to which courts actually play an impartial role in a political system depends in large part on the general organization of the judiciary and, more precisely, on the

\footnotetext{
168. From the perspective of democratic theory and evolutionary economics, valid institutional development and innovation arise from competition. The vicissitudes along the road of social development are not pre-determined. See Zhu (2006), p. 556.

169. Nagel (1976).

170. Li (2000), pp. 20-34.

171. He, supra note 73 , pp. 203-25.

172. Guarnieri (2009), pp. 242-5; Xin, supra note 13, pp. 203-25.

173. Li, supra note 170 , pp. 20-34.

174. He, supra note 73, p. 204.

175. Li, supra note 170 , pp. 20-34.

176. Cabestan (2005), p. 47.

177. Ibid.

178. Guarnieri, supra note 172 , p. 240.
} 
composition of the reference group of the judiciary. ${ }^{179}$ The increasing professionalism of the judges is likely to support the development of a stronger judicial identity; at the same time, it results in the reference group of judges "being composed mostly of other lawyers, especially fellow judges and academics," with the consequence that it will be difficult for the regime to control the cultural orientation of judges. ${ }^{180}$

The particular significance of the influence of legal scholars is also noted here because it can support a corresponding evolution in judicial culture and help to form the predominant concept of the judicial role: particularly "the way judges think they should behave." ${ }^{\prime 81}$ As asserted by scholars and remarked by the Supreme Court, a series of judicial reforms are due to the efforts of Chinese academics who have challenged the role of the $\mathrm{CCP}$ on specific case adjudication. ${ }^{182}$ At the same time, Suli and Cabestan's research has revealed that the CCP is also interested in "pushing forward the establishment of a 'rule by law' and a professional and autonomous court system"183 to open a more reliable avenue for dispute settlement, to keep social stability, and, in the end, to enhance the legitimacy of its leadership. ${ }^{184}$ Moreover, although seldom noticed, some scholars are aware that there are strong mechanisms for the judiciary to utilize the "interpretations" issued by the Supreme People's Court ${ }^{185}$ and local-level opinions together with occasional notices and opinions issued by individual court systems. ${ }^{186}$ As a result, by interpreting the law creatively and strategically, the courts can advance their own institutional interests and compete in the struggle for power and legitimacy with other political actors.

While admitting the active role of judges in the judiciary, this school also argues for the need to be acutely aware of the political circumstances within which the judges execute their power. ${ }^{187}$ Their "political embeddedness and resource constraints" ${ }^{188}$ determine that, rather than pursuing an aggressive power-maximization strategy, it is better for courts to first rely on or co-operate with the CCP and/or government to carry out the social-control function demanded by the state. ${ }^{189}$ Based on this fact, some scholars argue that, before questioning the courts' independence in the adjudication of disputes, we need to ask whether they in fact have the ability to make decisions independently. ${ }^{190}$ Moreover, according to a comparative study of East Asian countries (especially the Japanese model of judicial independence), these

\footnotetext{
179. Ibid., p. 243.

180. Ibid., pp. 240-1.

181. Ibid.
}

182. He (1998); 人民法院五年改革纲要 [The People's Court Five-Year Reform Plan], Zhonghua Renmin Gongheguo Zuigao Renmin FayuanGongbao, no. 6 (1999).

183. Cabestan, supra note 176, p. 48.

184. Ibid., p. 48.

185. The bureaucratic instructions liberally issued in the PRC court system that constitutes the "explanations" issued by the Supreme People's Court. As many Chinese academics, lawyers, and judges note, the Supreme People's Court regulations are a condition precedent to the application of certain provisions of law or doctrine by courts, which implies that the important provisions of law cannot be applied until regulations specifically addressing use of the provision have been issued; see Howson (2009).

186. Although the local-level opinions are normatively not as authoritative as Supreme People's Court regulations, in reality, they can be more powerful in the handling of actual cases at the non-central level, as acknowledged by the local judges; see ibid., pp. 149, 151.

187. He, supra note 73 , pp. 222-3.

188. Ibid.

189. Ibid.

190. Li (2009), p. 220. 
scholars highlight the instruments that emphasize "collective independence of the judiciary as a whole rather than the independence of individual judges," ${ }^{191}$ because the former can act with relative uniformity, and can compete for resources against other government agencies. $^{192}$

To a greater extent than hitherto recognized, the third school provides more complex and subtle insights into the judiciary's active role in its relationships with other actors in China's power structure. Scholars in this school emphasize that the courts do not simply yield to the pressures exerted on them by the Party, governments, or other external forces. As Xin He explains, "under the seemingly peaceful surface of iron control exists dynamic turbulences of conflict, repression, resistance, competition, compromise, and cooperation in which law, power, and politics interact." 193

However, when the third school highlights the interaction between the judicial system and the political actors in China, especially the CCP and government, it overlooks the influence on adjudicative independence from social powers in China such as media and litigants. Moreover, while this school is applying the "strategic interaction approach" to explore the interaction between the courts and other political actors in shaping the extent of judicial independence in China, it seems that the real effects of the interaction between different roles need to be fleshed out with empirical research.

More importantly, when this school values the crucial role of political circumstances within which the judges execute their power in influencing the extent of judicial independence, it fails to capture the dynamic process of the evolving of judicial independence according to the judicial power the CCP delegated to or withdrawn from the court system in different stages of the CCP's leadership. Therefore, this school offers no explicit explanation on the real source of judicial power, and correspondingly does not reveal the nature of judicial independence in China. Additionally, although this school touches the role of the legal scholar and the new "power centre" in judges and lawyers, the important role of the legal community in defending judicial independence is not fully examined.

The great debates over the issue of judicial independence also mark the different study approaches used by the three schools. Compared with the institutional approach, the second and third schools demonstrate new analytical frameworks with new research methods and highlight the importance of understanding and assessing China's judicial independence based on the interactions between the judiciary and other powers in China's historic and cultural context; these can certainly be usefully borrowed in studying judicial independence in China. Nevertheless, as Suli asserts, "conclusions about China's judicial system cannot be reached simply through debates; they will come as the result of empirical research."194

Unlike the theoretical understandings, the very different findings drawn from the fieldwork also reveal the importance of studying judicial independence in an empirical way. For instance, Gechlik and Zhang Wei's empirical work in Shanghai courts to check judicial fairness in China shows that judges in Shanghai suffer the least interference, which is due largely to Shanghai officials' greater respect for law and additionally to the greater economic

191. Ginsburg, supra note 138, p. 253.

192. Ibid., p. 253.

193. He (2009), p. 193.

194. Zhu, supra note 168 , p. 536. 
development and lower guanxi culture. ${ }^{195}$ These differences lie on an often perceived but rarely studied fact that there is a gap between legal norms and social practices "which is the product of the foreign origin of the norms and the pre-modern nature of China's native society." ${ }^{196}$ Nevertheless, as Clarke observes, compared with the great need for measurable data about the Chinese legal system, "empirical work of any kind is rare," and attention to rural areas is virtually non-existent. ${ }^{197}$ Clarke believed that the reason lies in the notion that "Chinese and foreign scholars are not interested in empirical data or field research."198 Thus, the debates between these three schools give rise to a great need for empirical work to study judicial independence in China.

\subsection{Short Summary}

This review of the relevant literature has examined the existing research on the situation of judicial independence in China. Applying different definitions and approaches to examine the nature and measure the extent of judicial independence in China, the three schools of thoughts reviewed above provide many useful insights for understanding judicial independence in China. Although the variation of definition and measuring approach resulted in the collision on nature and the extent of judicial independence in China, most of the research focused on the extent of impartial adjudication to assess judicial independence based on the country's political structure. In Henderson's words, the legal concept of judicial independence in China "has usually been interpreted to only apply to the judicial decision-making process related to individual cases - not the institutional independence of the judiciary."199

However, each of these three schools of thought has its shortcomings, especially in that they failed to capture the complicated nature and the dynamic process of the evolving of judicial independence according to the judicial power the CCP delegated to or withdrawn from the court system in different stages of the CCP's leadership. Therefore, they offer no explicit explanation on the real source of judicial power, and correspondingly do not reveal the real nature of judicial independence in China. Moreover, the strength of the legal community in defending judicial independence is not fully explained, although the third school touches on it.

\section{CONCLUSION}

Due to China's political system and legal culture, the judicial decision-making process in contemporary China is more complicated than conventionally appreciated, because it involves the interactions of aspects of law, politics, and power. Moreover, giving a chronological review of the development of the CCP's judicial policies on courts, one can also notice that the extent of judicial independence in China is not fixed, but varies with the amount of judicial discretion afforded by the CCP to judges, and deeply influenced by

\footnotetext{
195. Gechlik (2005), p. 97; Zheng (2004).

196. Clarke (2003).

197. Zhu (2000).

198. Clarke, supra note 196, p. 3.

199. Henderson, supra note 83, p. 28.
} 
China's traditional legal philosophy and the CCP's revolutionary and pre-revolutionary history.

Therefore, in order to portray the true extent of judicial independence in China's judicial practices, this article argues that, based on China's social and political environments, judicial independence should be defined in a narrow way, focusing on judicial adjudication independence (审判独立) to analyze different factors that are likely to affect judicial behaviour and how those factors influence and shape the judges' decision-making process. At the same time, a detailed chronological review of the evolving of the Party's judicial policy should be conducted to explore the dynamic process of the development of judicial independence in China and its implications. Furthermore, in order to seek a deeper understanding of the nature and extent of judicial independence in China, apart from the institutional arrangements, the actual- "on the ground"-functioning of China's courts and other legal institutions should be studied and a number of factors including elements of law, different powerful interests, and politics also should be taken into account.

\section{REFERENCES}

Austen-Smith, David, \& Jeffrey S. Banks (1998) "Social Choice Theory, Game Theory, and Positive Political Theory." 1 Annual Review of Political Science 259-87.

Avino, Graig R. (2003) "China's Judiciary: An Instrument of Democratic Change." 22 Penn State International Law Review 369-92.

Bailyn, Bernard (1992) The Ideological Origins of the American Revolution, Cambridge: The Belknap Press of Harvard University Press.

Balme, Stephanie (2010) "Local Courts in Western China: The Quest for Independence and Dignity," in R. Peerenboom, ed, Judicial Independence in China, Cambridge: Cambridge University Press, 154-79.

Becker, Theodore L. (1970) Comparative Judicial Politics: The Political Functionings of Courts, Chicago: Rand McNally.

Cabestan, Jean-Pierre (2005) "The Political and Practical Obstacles to the Reform of the Judiciary and the Establishment of a Rule of Law in China." 10 Journal of Chinese Political Science 43-64.

Casanova, Pablo G., Danielle Salti, \& Irving L. Horowitz (1970) Democracy in Mexico, Oxford: Oxford University Press.

Chen, Guangzhong (2013) “比较法视野下的中国特色司法独立原则 [The Principal of Judicial Independence with Chinese Characteristics in the Perspective of Comparative Law].” 27 比较法研 究 [Journal of Comparative Law] 1-12.

Chen, Jianfu (1999) Chinese law: Towards an Understanding of Chinese law, Its Nature, and Development, The Hague: Kluwer Law International.

Chow, Daniel C. K. (2015) The Legal System of the People's Republic of China in a Nutshell, Saint Paul: Western Academic.

Christie, George C. (1986) "An Essay on Discretion.” 35 Duke Law Journal 747-78.

Clark, David S. (1974) "Judicial Protection of the Constitution in Latin America." 2 Hastings Constitutional Law Quarterly 405.

Clark, Tom S., \& Jeffrey K. Staton (2011) "Challenges and Opportunities of Judicial Independence Research." 21 Newsletter of the Law \& Courts Section of the American Political Science Association $10-16$.

Clarke, Donald C. (2003) "Empirical Research into the Chinese Judicial System," https://papers.ssrn. com/sol3/papers.cfm?abstract_id=412660 (accessed 1 May 2018).

Cohen, J. Alan (1969) "The Chinese Communist Party and 'Judicial Independence': 1949-1959." 82 Harvard Law Review 967-1006. 
Dam, Kenneth W. (2007) The Law-Growth Nexus: The Rule of Law and Economic Development, Washington: Brookings Institution Press.

Dawson, John P. (1968) "The Oracles of the Law." 13 American Journal of Legal History 166-8.

Dirlik, Arif (1985) "Culture, Society and Revolution: A Critical Discussion of American Studies of Modern Chinese Thought." Working Papers in Asian/Pacific Studies 1, Asian/Pacific Studies Institute, Duke University.

Dong, Chao (2005) “司法独立在中国 [Judicial Independence in China].” 1 政法论坛 [Journey of Political Science and Law] 6-13.

Epstein, Lee, \& Jack Knight (1997) The Choices Justices Make, Washington, DC: Congressional Quarterly Press.

Evans, Peter (2004) "Development as Institutional Change: The Pitfalls of Monocropping and the Potentials of Deliberation." 38 Studies in Comparative International Development 30-52.

Fairlie, John A. (1923) "The Separation of Powers.” 21 Michigan Law Review 393-436.

Ferejohn, John (1999) "Independent Judges, Dependent Judiciary: Explaining Judicial Independence, Judicial Independence and Accountability Symposium." 72 Southern California Law Review 353-84.

Finder, Susan (1995) "Inside the People's Courts: China Litigation System and the Resolution of Commercial Disputes," in C. Hunter, ed, Dispute Resolution in the PRC: A Practical Guide to Litigation and Arbitration in China, Hong Kong: China Law and Practice, 63-73.

Fiss, Owen M. (1993) "The Limits of Judicial Independence." 25 The University of Miami InterAmerican Law Review 157-76.

Fu, Yulin, \& Randall Peerenboom (2009) "A New Analytic Framework for Understanding and Promoting Judicial Independence in China," in R. Peerenboom, ed, Judicial Independence in China: Lessons for Global Rule of Law Promotion, New York: Cambridge University Press, 95-133.

Garapon, Antoine (2009) “A New Approach for Promoting Judicial Independence,” in R. Peerenboom, ed, Judicial Independence in China: Lessons for Global Rule of Law Promotion, New York: Cambridge University Press, 37-51.

Gechlik, Mei Y. (2005) "Judicial Reform in China: Lessons from Shanghai." 19 Columbia Journal of Asian Law 97-137.

Gibson, James L. (2009) "'New-style' Judicial Campaigns and the Legitimacy of State High Courts." 71 Journal of Politics 1285-304.

Ginsburg, Tom (2010) "Judicial Independence in East Asia: Implications for China," in R. Peerenboom, ed, Judicial Independence in China, New York: Cambridge University Press, 247-59.

Guarnieri, Carlo (2001) "Judicial Independence in Latin Countries of Western Europe," in P. H. Russell \& D. M. O'Brien, eds., Judicial Independence in the Age of Democracy: Critical Perspectives from Around the World, Charlottesville: University Press of Virginia, 111-30.

Guarnieri, Carlo (2009) "Judicial Independence in Authoritarian Regimes," in R. Peerenboom, ed, Judicial Independence in China: Lessons for Global Rule of Law Promotion, New York: Cambridge University Press, 234-46.

Hart, Henry M. Jr, \& Herbert Wechsler (1953) The Federal Courts and the Federal System, Brooklyn: Foundation Press.

He, Weifang (1998) “复转军人进法院 [Discharged Military Officers Come to the Court],”南方周末 [Southern Weekly], 2 January.

He, Weifang (2002) “谁是司法改革的主导 [Who Can Initiate Judicial Reforms], 人民法院报 [People's Court Daily], 12 September.

He, Weifang (2003) “中国的法院改革与司法独立: 一个参与者的观察与反思 [Judicial Reform and Judicial Independence in China: A Particant's Observation and Reflection].” 2 浙江社会科学 [Zhejiang Social Sciences] 83-7.

$\mathrm{He}$, Xin (2004) "Ideology Or Reality? Limited Judicial Independence in Contemporary Rural China." 6 Asian Law 213-30.

He, Xin (2007) "Why Did They Not Take on the Disputes? Law, Power and Politics in the Decisionmaking of Chinese Courts." 3 International Journal of Law in Context 203-25. 
He, Xin (2009) "The Judiciary Pushes Back: Law, Power, and Politics in Chinese Courts," in R. Peerenboom, ed, Judicial Independence in China: Lessons for Global Rule of Law Promotion, New York: Cambridge University Press, 180-95.

Henderson, Keith E. (2009) "Halfway Home and a Long Way to Go: China's Rule of Law Evolution and the Global Road to Judicial Independence, Judicial Impartiality, and Judicial Integrity," in R. Peerenboom, ed, Judicial Independence in China: Lessons for Global Rule of Law Promotion, New York: Cambridge University Press, 23-36.

Horsky, Charles A. (1957) "Law Day: Some Reflections on Current Proposals to Curtail the Supreme Court." 6 Minnesota Law Review 1105-09.

Howson, Nicholas C. (2009) "Judicial Independence and the Company Law in the Shanghai Courts," in R. Peerenboom, ed, Judicial Independence in China: Lessons for Global Rule of Law Promotion, New York: Cambridge University Press, 134-53.

Huber, John D., \& Charles R. Shipan (2002) Deliberate Discretion?: The Institutional Foundations of Bureaucratic Autonomy, Cambridge: Cambridge University Press.

Huntington, Samuel P. (2006) Political Order in Changing Societies, New Haven: Yale University Press.

Kaufman, Irving R. (1980) “The Essence of Judicial Independence.” 80 Columbia Law Review 671-701.

Killion, M. Ulric (2004) “Post-WTO China and Independent Judicial Review.” 26 Houston Journal of International Law 507-60.

Kornhauser, Lexis A. (2002) "Is Judicial Independence a Useful Concept?,” in Stephen B. Burbank, ed, Judicial Independence at the Crossroads: An Interdisciplinary Approach, California: Sage Publication Inc, 45-54.

Larkins, Christopher M. (1996) "Judicial Independence and Democratization: A Theoretical and Conceptual Analysis." 44 The American Journal of Comparative Law 605-26.

Lee, Tahirih V. ed. (1997) Contract, Guanxi, and Dispute Resolution in China, Vol. 3 Abingdon: Routledge.

$\mathrm{Li}$, Ling (2009) "Corruption in China's Courts," in R. Peerenboom, ed, Judicial Independence in China: Lessons for Global Rule of Law Promotion, New York: Cambridge University Press, 196-220.

Li, Yuwen (2000) "Lawyers in China, A 'Florishing' Profession in a Rapidly Changing Society?" 27 China Perspectives 20-34.

Liang, Jianbing (2010) “司法独立已经实现?! [Judicial Independence has been Achieved?!],” http://article.chinalawinfo.com/ArticleHtml/Article_57015.shtml (accessed 7 December 2016).

Liebman, Benjamin L. (2005) "Watchdog or Demagogue? The Media in the Chinese Legal System." 105 Columbia Law Review 1-157.

Lubman, Stanley (1999) "Bird in a Cage: Chinese Law Reform after Twenty Years." 20 Northwestern Journal of International Law \& Business 383-424.

McCubbins, Mathew D., Roger Noll, \& Barry Weingast (1994) "Legislative Intent: The Use of Positive Political Theory in Statutory Interpretation." 57 Law and Contemporary Problems 3-37.

McCubbins, Mathew D., Roger Noll, \& Barry Weingast (2005) "The Political Economy of Law: Decision-making by Judicial, Legislative, Executive and Administrative Agencies." 4-35 Stanford Institute for Economic Policy Research Discussion Papers.

McCubbins, Mathew D., Roger Noll, \& Barry Weingast (2006) "Conditions for Judicial Independence." 15 Maryland Journal of Contemporary Legal Issues 105-28.

Mcpherson, Stephen. L. (2008) "Crossing the River by Feeling the Stones: The Path to Judicial Independence in China.” 26 Penn State International Law Review 787-810.

Michelson, Ethan (2007) "Lawyers, Political Embeddedness, and Institutional Continuity in China's Transition from Socialism.” 113 American Journal of Sociology 352-414.

Michelson, Ethan (2008) "Dispute Processing in Urban and Rural China: Findings from Two Surveys, Dispute Resolution in China." 6 The Foundation for Law, Justice and Society 1-8.

Minegar, Steven R. (2011) "Judicial Accountability Versus the Separation of Powers: Perspectives on Brazil's National Council of Justice.” 21 International Criminal Justice Review 383-401. 
Montesquieu, Charles de (1955) The Spirit of the Laws, Chicago: Encyclopaedia Britannica.

Nagel, Jack H. (1976) The Descriptive Analysis of Power, New Haven: Yale University Press.

Nicholson, Robert D. (1993) "Judicial Independence and Accountability: Can They Co-Exist?" 67 Australian Law Journal 404.

O'Brien, Kevin J., \& Lianjiang Li (2004) "Suing the Local State: Administrative Litigation in Rural China." 51 China Journal 75-96.

Peerenboom, Randall (2001) "Let One Hundred Flowers Bloom, One Hundred Schools Contend: Debating Rule of Law in China." 23 Michigan Journal of International Law 471-544.

Peerenboom, Randall (2009) "Judicial Independence in China: Common Myths and Unfounded Assumptions," in R. Peerenboom, ed., Judicial Independence in China: Lessons for Global Rule of Law Promotion, New York: Cambridge University Press, 69-94.

People.com (1978) “中国共产党第十一届中央委员会第三次会议公报 [The Communiqué of the Third Plenary Session of the Eleventh Central Committee of the Communist Party of China]," http:// cpc.people.com.cn/GB/64162/64168/64563/65371/4441902.html (accessed 18 July 2016).

Popova, Maria D. (2006) "Judicial Independence and Political Competition: Electoral and Defamation Disputes in Russia and Ukraine." PhD diss., Harvard University.

Ramseyer, J. Mark (1994) "The Puzzling (In) Dependence of Courts: A Comparative Approach." 23 Journal of Legal Studies 721-47.

Rosenberg, Gerald N. (1992) "Judicial Independence and the Reality of Political Power." 54 Review of Politics 369-98.

Russell, Peter H. (2001) "Toward A General Theory of Judicial Independence," in P. Russell \& D. O'Brien, eds., Judicial Independence in the Age of Democracy: Critical Perspectives from Around the World, Charlottesville: University Press of Virginia, 1-25.

Salzberger, Eli M. (1993) "A Positive Analysis of the Doctrine of Separation of Powers, or: Why Do We Have An Independent Judiciary?" 13 International Review of Law \& Economics 349-79.

Shapiro, Martin (1981) Courts: A Comparative and Political Analysis, Chicago: The University of Chicago Press.

Shapiro, Martin (1988) Who Guards the Guardians? Judicial Control of Administration, Athens: University of Georgia Press.

Shetreet, Shimon, \& Jules Deschênes (1985) Judicial Independence: The Contemporary Debate, Netherlands: Martinus Nijhoff Publishers.

Song, Jianli (2007) "China's Judiciary: Current Issues." 59 Maine Law Review 141-8.

Stevens, R. (1999) "A Loss of Innocence? Judicial Independence and the Separation of Powers." 19 Oxford Journal of Legal Studies 365-402.

Tay, Alice E. S. (1987) "The Struggle for Law in China." 21 University of British Columbia Law Review 561-80.

Tiede, Lydia B. (2006) "Judicial Independence: Often Cited, Rarely Understood." 15 Journal of Contemporary Legal Issues 129-61.

Trochim, William M. K., \& James P. Donnelly (2001) Research Methods Knowledge Base, Cincinnati: Atomic Dog Publishing.

Upham, Frank K. (2005) "Who Will Find the Defendant if He Stays with His Sheep? Justice in Rural China." 114 Yale Law Journal 1675-718.

Valelly, Richard M. (2009) Princeton Readings in American Politics, Princeton: Princeton University Press.

Vanberg, Georg (2008) "Establishing and Maintaining Judicial Independence," in G. Caldeira, R. Kelemen \& K. Whittington, eds., The Oxford Handbook of Law and Politics, Oxford: Oxford University Press, 99-118.

Westen, Peter (1983) "The Meaning of Equality in Law, Science, Math, and Morals: A Reply." 81 Michigan Law Review 604-63.

Wu, Lei, ed. (1997) 中国司法独立 [Judicial System in China], Beijing: China People's University Press.

Xin, Chunying (2003) "What Kind of Judicial Power Does China Need?" 1 International Journal of Constitutional Law 58-78. 
Xu, Xiaoqun (1997) “The Fate of Judicial Independence in Republican China, 1912-37." 149 China Quarterly 1-28.

Yang, Jianjun (2013) “司法的中国特色 [Judicial with Chinese Characteristics].” 1 法律科学 [Legal Science] 3-14.

Yardley, Jim (2005) “A Judge Tests China's Courts, Making History," The New York Times, 28 November.

Zhao, Ming (2008) “从历史的深处走来——漫议转型时期的当代中国政治与司法改革 [Coming from History-On Relationship of China' s Judicial System Reform and Political System Reform].” 3 政法论丛 [Journal of Political Science and Law] 3-14.

Zheng, Wen (2004) 上海：领导干部学法用法取得明显效果 [Shanghai: Leading Cadres' Legal Education and Application of Law Have Yielded Obvious Results], 法制日报 [Legal Daily], 7 December.

Zhu, Suli (2000) 送法下乡：中国基层司法制度研究 [Sending Law to the Countryside: Research on China's Basic-Level Judicial System], Beijing: China University of Political Science and Law Press. Zhu, Suli (2006) "Political Parties in China's Judiciary." 17 Duke Journal of Comparative and International Law 533-60.

Zhu, Suli (2009) "The Party and the Courts," in R. Peerenboom, ed., Judicial Independence in China, New York: Cambridge University Press, 52-68.

Zuo, Weimin (2015) “省级统管地方法院法官任用改革审思 [Reflections on the Reform of Centralizing the Appointment of Local Judges to the Provincial Level].” 4 法学研究 [Chinese Journal of Law] 23-40. 